\title{
A model of reopening businesses to decrease the heath and economic impacts of the COVID-19 pandemic: Lessons from Iran
}

\author{
Hesam Seyedin ${ }^{1}$, Ali-Mohamad Zanganeh*2 (D), Mohammadbagher Mojtabaei ${ }^{3}$, Rafat Bagherzadeh ${ }^{4}$, Hushyar Faghihi ${ }^{5}$ \\ Received: 19 May 2020 \\ Published: 12 Aug 2020
}

\begin{abstract}
Background: OVID-19 is a major cause of morbidity and mortality worldwide. The closure of governmental and nongovernmental centers as well as social, cultural, and economic activities are other major negative impacts of the virus. The present paper aimed to develop a model of economic and health-related factors which affect the reopening of businesses and the proper management of the effect of virus on different aspects, particularly on people's health and economy.

Methods: In order to facilitate decision-making and model risk analysis of guilds and occupations, an expert panel, including eight 8 experts, was convened by the Ministry of Health in Iran to prepare a strategic framework for the national taskforce of COVID-19 management. The panel spent many hours to prepare a simple model of reopening businesses and prioritize them from low to high risks.

Results: The experts identified and weighed seven health and three economic-related factors. The businesses and jobs were classified into 69 categories based on their similarities; they were also graded according to a predefined five- point Likert scale and categorized into three levels of low, medium, and high risk. The policymakers recommended to reopen businesses stratified by risk levels at least two weeks' intervals.

Conclusion: The relaunch strategy in Iran put health and safety first while gradually reopening businesses, resuming activities, and getting people back to work. At the same time, attempts were made to slow the spread of the virus through following public health measures, social distancing, good hygiene, and continued acting responsibly. As many countries may have to deal with the same issue, this model can help them adopt appropriate policies and strategies for disease containment.
\end{abstract}

Keywords: COVID-19, Health policy, Public health, Disaster management, Risk analysis, Business, Job, Relaunching business, Pandemic, Model

Conflicts of Interest: None declared

Funding: None

*This work has been published under CC BY-NC-SA 1.0 license.

Copyright $\odot$ Iran University of Medical Sciences

Cite this article as: Seyedin H, Zanganeh AM, Mojtabaei M, Bagherzadeh R, Faghihi H. A model of reopening businesses to decrease the heath and economic impacts of the COVID-19 pandemic: Lessons from Iran. Med J Islam Repub Iran. 2020 (12 Aug);34:97. https://doi.org/10.47176/mjiri.34.97

\section{Introduction}

Coronavirus Disease 2019 (COVID-19) has spread from China to many other countries around the world, including Iran. With regards to the global spread of the disease and

Corresponding author: Dr Ali-Mohamad Zanganeh,am.zanganeh@iums.ac.ir

1. Health Management and Economics Research Center, Department of Health in Emergency and Disasters, School of Health Management and Information Science, Iran University of Medical Sciences, Tehran, Iran

2. Department of Health Services Management, School of Health Management and Information Sciences, Iran University of Medical Sciences, Tehran, Iran

3. Economy \& Planning Senior Advisor at Iran Chamber of Guilds (Small \& Medium Enterprises), Tehran, Iran

4. English Department, School of Health Management \& Information Sciences, Iran University of Medical Sciences, Tehran, Iran

5. Economy Deputy at Iran Chamber of Guilds (Small \& Medium Enterprises), Tehran, Iran its impact on all segments of societies, it seems that this issue would have a wide range of unimaginable dimensions (1-3) .Based on the severity of its international impacts, the

$\uparrow$ What is "already known" in this topic:

The worldwide spread of the Coronavirus disease 2019 (COVID-19) first detected in Wuhan, China, has increased mortality and economic loss, and negatively affected the social determinants of health in all communities. The World Health Organization (WHO) and various countries tried to lessen the impacts of the virus by adopting different policies.

\section{$\rightarrow$ What this article adds:}

In this study, appropriate strategies were used to decrease the spread of the disease and lower its impact on the community, reduce transmission among employees, and maintain healthy business operations. Findings of this study could help policymakers and WHO conduct further studies and find global policies and strategies for disease containment. 
outbreak conditions have greatly affected all aspects of daily life, such as travel, trade, tourism, food supplies, and financial markets, especially during the pandemic. The global spread of the coronavirus disease has triggered an array of public health responses (4). Illness and death are the only visible effects of the COVID-19 in societies. The closure of governmental and nongovernmental centers as well as social, cultural, and economic activities are other major negative impacts of the virus.

The long-term effects of the virus on social determinants of health (SDH), the burden of the disease, and the financial burden in the society will certainly have an upward trend $(5,6)$; therefore, it is essential to manage the reopening of centers and jobs and take necessary precautions to minimize the consequences of the spread of the disease and its indirect effects on the health of the society (7).

COVID-19 came with a heavy socioeconomic price too, particularly in low and middle- income countries with limited capacities. Bankruptcy and unemployment will have devastating consequences on the lives of vulnerable populations (8). Therefore, it is crucial to properly manage its influences on different aspects, particularly on people's health. Moreover, there should be a plan for reactivating the society, restarting work and production, and resuming travels and education (8).

To date, there is no effective vaccine to control the COVID19 pandemic, and the only solution is to prevent or slow person-to-person transmission (9). Some countries followed certain guidelines to reopen their businesses .Iran also adopted some principled policies and took measures prior to reopening businesses, such as implementing social distancing regulations, communicating appropriate protocols, rules and regulations, and monitoring their proper implementation to minimize the risks caused by the disease.

As a result, it is necessary to consider the best strategies to decrease the spread of the disease and lower its impact on the community, reduce transmission among employees, and maintain healthy business operations and work environment in accordance with local needs, health care capacities, and resiliency (10).

Due to limited available information on coronavirus, we are still learning about it; therefore, the current study was conducted to develop a model of re-opening businesses in Iran.

\section{Methods}

In order to facilitate decision-making and modeling risk analysis of guilds and occupations, an expert panel $(\mathrm{N}=8)$ was convened by the Ministry of Health in Iran to prepare a strategic framework for the national taskforce of COVID19 management. The panel focused on the following thematic blocks: the risk of disease transmission, population density, contacts facilitating disease transmission, risk reduction and control strategies, and future of work, unemployment, economic dilemmas, and the disease burden.

Moreover, the following questions were addressed by the panel:

1.What are the effects of reopening businesses and jobs on the risk of COVID-19 disease transmission, containment, and mitigation strategies in disease management?
2.What are the challenges of re-opening businesses and jobs and how can we cope with or respond to these challenges?

3.What elements should be considered during the early phase of reopening jobs to ensure safer conditions and slow down the spread of the virus?

The panel spent many hours to prepare a simple model of re-opening businesses and prioritize them from low to high risk.

\section{Results}

In order to avoid a one-sided view of health issues in reopening businesses, the experts agreed to include two major economic and health variables. They identified and weighed seven health and three economic-related factors. Health-related factors, in the total burden of disease, are more important than economic factors; therefore, the ratio of $70 \%$ and $30 \%$ was considered in weighing these two variables, respectively.

Although there are many variables to assess the economic and health impacts of the coronavirus, only a limited number of essential factors, due to time constraints, were selected and included in the model. The economic indicators used in this study included the impact of businesses on satisfying the essential needs of the society, the number of direct jobs created by businesses, and the role and importance of businesses in the supply chain and distribution channels. The production and distribution chain refers to the flow of goods after the selected business.

Furthermore, seven indicators of disease prevalence were considered, i.e., the communication time and the time a customer spends at the business area, population density, and the average number of customers in the business area, ventilation and airflow in the relevant space, the frequency of contacts among employees, the frequency of contacts among the employees and customers, the frequency of new people visiting the place, and the probability of product contamination during the production or distribution process. Bulk products are more likely to be contaminated than packaged products.

The indicators and their weighted coefficient are demonstrated in Table 1.

The businesses and jobs were classified into 69 categories based on their similarities (Table 2).

However, religious institutions, leisure and tourism centers, sports centers, cultural and artistic centers, administrative and social service centers, residential service centers, educational centers and transportation centers were excluded from the list. Bakeries, gas stations, food chain stores, supermarkets, pharmacies, health centers, centers providing medical supplies and equipment, fruit and vegetable shops, fruit and vegetable markets, centers selling protein and dairy products, catering and outdoor food, services such as car and house repair and installations, veterinaries, drug and food distribution centers, and ambulance services were also omitted from the aforementioned list since they provided the essential needs of the people and were not closed during the outbreak.

Using an Excel worksheet, the researchers graded the grouped businesses according to a predefined five-point 


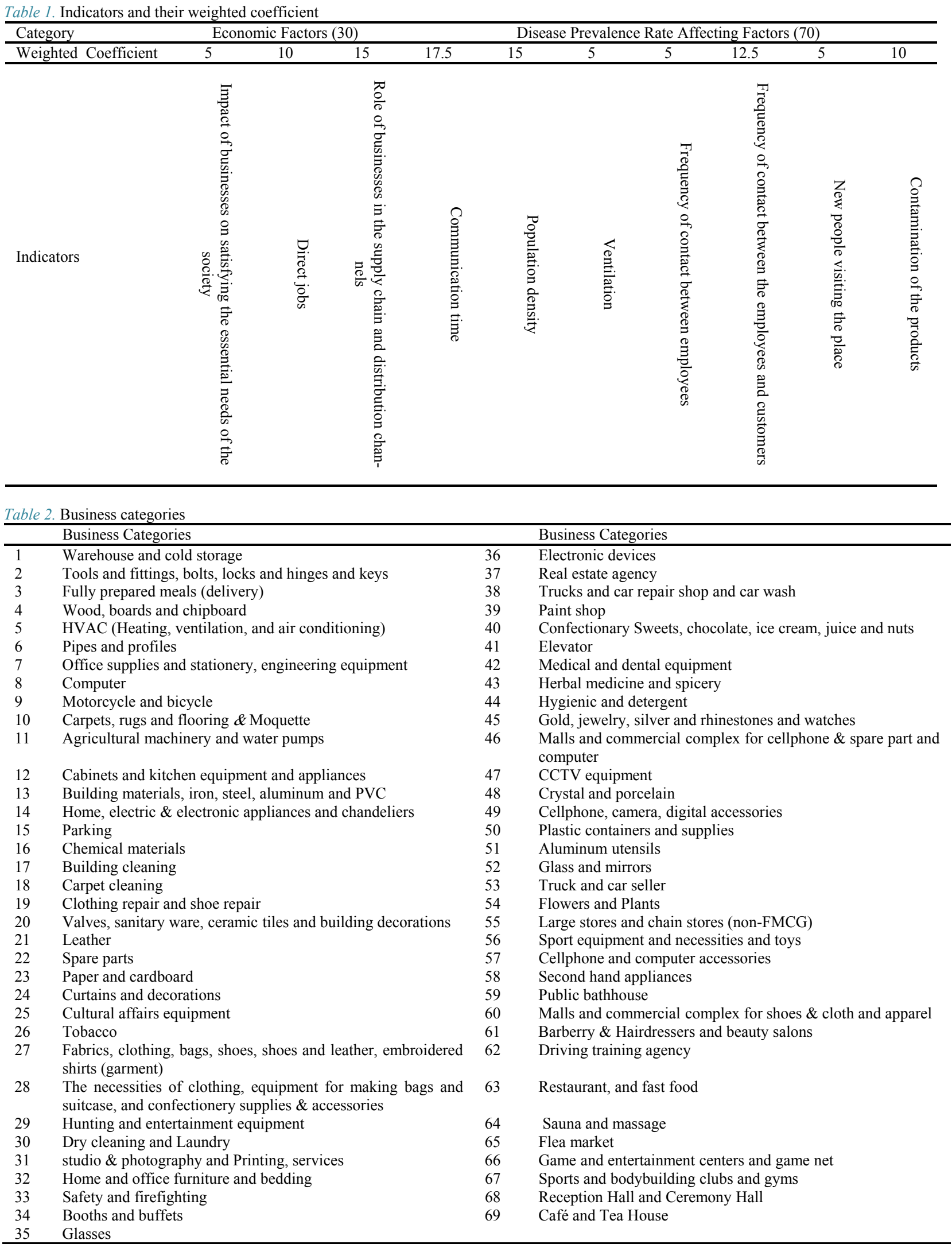

Likert scale for each indicator. The mean scores of all 10 indicators for each group ranged from one to five. According to the findings, the businesses were categorized into three levels of low (green color), medium (yellow color), and high risk (red color). Finally, the policymakers were recommended to reopen businesses stratified by risk levels at least in two weeks' intervals to have sufficient time to study the behavior of the virus after each reopening step. 


\section{Discussion}

COVID-19 affected public health along with the economy. The closure of governmental and nongovernmental centers as well as social, cultural, and economic activities are other major negative impacts of the virus. In reopening business and jobs, it is necessary to adopt proper strategies to decrease the spread of the virus in community, reduce transmission among employees, and maintain healthy business operations. In this paper a model of reopening businesses was developed to decrease the heath and economic impacts of the COVID-19 pandemic and to properly manage the effect of the virus on different aspects, particularly on people's health and economy in Iran.

Bartik et al. conducted a survey on more than 5,800 small businesses in the United States. They found that 43 percent of businesses had temporarily closed, and nearly all of these closures were due to COVID. The results also demonstrated the financial vulnerability of many businesses to the crisis (11). The ultimate financial loss caused by COVID-19 cannot be predicted. Results of a study showed that on average, each additional month of crisis costs $2.5-3 \%$ of global GDP (12).

In this study, the following economic indicators were used: (1) The impact of businesses on satisfying the essential needs of the society, (2) The number of direct jobs created by businesses, and (3) The role and importance of businesses in the supply chain and distribution channels. Moreover, seven indicators of disease prevalence were considered, such as the contamination of products, population density, ventilation, frequency of contact between the employees and customers, frequency of contact between employees, and new people visiting the place.

A study conducted on New Orleans businesses to understand factors influencing decisions to re-open them. Some businesses, such as professional, scientific, and technical services reopened soon, while others were classified and are supposed to reopen later. These findings accentuate the need for public policy and emergency plans and their ontime implementation prior to making any decision on closing or reopening businesses (13).

In their study, Zimmermann et al. considered the following factors in assessing the transmission risk: (1) workplace size, (2) human interactions, (3) inability to work from home, and (4) industry size. According to the findings, states should reopen gradually and should not be motivated by political agenda (14).

Andersen et al. designed some reopening strategies in Denmark. They believed that in case of restrictions, all aspects should be taken into consideration to assess their costbenefit ratios. Moreover, they asserted that reopening can be facilitated if behavioral responses, such as physical distancing and hygiene are observed by the people even at the time of less formal lockdown restrictions (15).

In another study, the researchers considered the possibility of gradual reopening of the U.S industry. They classified industries based on their degree of contact intensity, that is, the required degree of physical proximity as well as their reliance on intermediate inputs from contact-intensive industries. According to the findings, universities and religious organizations were ranked as requiring low physical contact exposure. The aforementioned index of physical contact exposure, according to this study can facilitate the identification of the most/least contact-intensive industries or the ones which are the most / least reliant on inputs from contact-intensive industries. They came to the conclusion that prior to making any decisions about reopening the industries, one should consider the fact that if these industries can work remotely (16).

Overall, peoples' health should be a major priority and reopening, businesses stratified by risk levels at least in two weeks' intervals, provides sufficient time to study the behavior of the virus after each reopening step.

\section{Conclusion}

As many countries might encounter the same problems in re-opening businesses, this model can help them adopt appropriate policies and strategies for disease containment. Moreover, the model can be used as a guide for reopening businesses in other countries whose policymakers are advised to review all relevant criteria in accordance with their local needs, health care capacities, and resiliency in response to the pandemic and their purposes of reopening. COVID-19 is a novel infectious disease and we are not appropriately prepared to respond to it; therefore, we need to learn from other countries to determine the optimal approach suitable for our specific settings.

\section{Acknowledgement}

Authors wish to thank AliAkbar Haghdoost, Saeed Mombeini, Zakaria Hoseini, Hosein Shomali, Mehdi Mojabi, and Zahra Manouchehrabadi for their participation and kind cooperation.

\section{Conflict of Interests}

The authors declare that they have no competing interests.

\section{References}

1. Binagwaho A. We Need Compassionate Leadership Management Based on Evidence to Defeat COVID-19. Int J Health Policy Manag. 2020.

2. Laing T. The economic impact of the Coronavirus 2019 (Covid-2019): Implications for the mining industry. Extract Indust Soc. 2020;7(2):580-582.

3. Shokri A, Moradi G, Piroozi B, Darvishi S, Amirhosseini S, Veysi A, et al. Perceived stress due to COVID-19 in Iran: Emphasizing the role of social networks. Med J Islam Repub Iran. 2020;34(1):400-3.

4. Bayham J, Fenichel EP. Impact of school closures for COVID-19 on the US health-care workforce and net mortality: a modelling study. Lancet Public Health. 2020;34(1).

5.Zaboli R, Tourani S, Seyedin SH, Oliaie Manesh A. Prioritizing the Determinants of Social-health Inequality in Iran: A Multiple Attribute Decision Making Application. Iran Red Crescent Med J. 2014;16(4):e12607.

6. Fazaeli AA, Seyedin H, Vosoogh Moghaddam A, Delavari A, Salimzadeh H, Varmazyar H, et al. Fairness of Financial Contribution in Iranian Health System: Trend Analysis of National Household Income and Expenditure, 2003-2010. Glob J Health Sci. 2015;7(5):2605 .

7. Mwacalimba KK, Green J. 'One health' and development priorities in resource-constrained countries: policy lessons from avian and pandemic influenza preparedness in Zambia. Health Policy Plan. 2014;30(2):215-22.

8. Petersen E, Wasserman S, Lee S-S, Go U, Holmes AH, Abri SA, et al. COVID-19-We urgently need to start developing an exit strategy. Int J 
Infect Dis. 2020;96:233-239.

9. Rowan NJ, Laffey JG. Challenges and solutions for addressing critical shortage of supply chain for personal and protective equipment (PPE) arising from Coronavirus disease (COVID19) pandemic - Case study from the Republic of Ireland. Sci Total Environ. 2020;725:138532.

10. Legido-Quigley H, Asgari N, Teo YY, Leung GM, Oshitani H, Fukuda K, et al. Are high-performing health systems resilient against the COVID-19 epidemic? Lancet. 2020;395(10227):848-50.

11. Bartik AW, Bertrand M, Cullen ZB, Glaeser EL, Luca M, Stanton CT. How are small businesses adjusting to covid-19? early evidence from a survey. Natl Bureau Econ Res. 2020;Report No.:0898-2937.

12. Fernandes NJAaS. Economic effects of coronavirus outbreak (COVID-19) on the world economy. 2020.

13. Lam NSN, Pace K, Campanella R, LeSage J, Arenas H. Business Return in New Orleans: Decision Making Amid Post-Katrina Uncertainty. PloS One. 2009;4(8):e6765.

14. Zimmermann M, Benefield AE, Althouse BM. They stumble that run fast: the economic and COVID-19 transmission impacts of reopening industries in the US. medRxiv; 2020.

15. Andersen TM, Schröder PJ, Svarer M. Designing Reopening Strategies in the Aftermath of COVID-19 Lockdowns: Some Principles with an Application to Denmark. Institute of Labor Economics (IZA); 2020.

16. Famiglietti M, Leibovici F, Santacreu AM. Reopening the US Economy an Industry at a Time. https://www.stlouisfed.org/on-theeconomy/2020/may/reopening-us-economy-industry-time; Access date first of June 2020. 